\title{
Metabolite Profiling of Three Curcuma Species (Zingiberaceae) Based on
} H-NMR Spectroscopy

\author{
Dinar Sari Cahyaningrum Wahyuni ${ }^{a^{*}}$, Mutya Puti Wardianti ${ }^{a}$, Yudi Rinanto ${ }^{b}$, \\ Soerya Dewi Marliyana ${ }^{c}$ \\ ${ }^{a}$ Pharmacy Department, Faculty of Mathematics and Natural Sciences, Universitas Sebelas Maret, Jl. Ir. \\ Sutami 36 A, Kentingan Surakarta 57126 telp. (0271) 663375 \\ ${ }^{b}$ Biology Education Program, Faculty of Teacher Training and Education, Universitas Sebelas Maret, Jl. Ir. \\ Sutami 36 A, Kentingan Surakarta 57126 telp. (0271) 663375 \\ ${ }^{c}$ Chemistry Department, Faculty of Mathematics and Natural Sciences, Universitas Sebelas Maret, Jl. Ir. \\ Sutami 36 A, Kentingan Surakarta 57126 telp. (0271) 663375 \\ * Corresponding author \\ E-mail: dinarsari_cw@staff.uns.ac.id \\ DOI:10.20961/alchemy.15.1.23914.79-88
}

Received 12 September 2018, Accepted 21 January 2019, Published 01 March 2019

\begin{abstract}
Genus Curcuma, Zingiberaceae, is a typical medicinal plant in tropical region especially in Indonesia. It has been studied to have antioxidant, antimicrobial, antitumor, anti-inflammatory and anticancer activities. However, little knowledge of the metabolic profile both primary and secondary metabolites have been reported. Thus, this study aims to investigate metabolic profiling both primary and secondary metabolites simultaneously in the Curcuma species based on proton nuclear magnetic resonance $\left({ }^{1} \mathrm{H}-\mathrm{NMR}\right)$ spectroscopy. The present work applied metabolomic study which measured the qualitative and quantitative characteristic metabolites. The Curcuma species, Curcuma aeruginosa Roxb., Curcuma xanthorrhiza Roxb., and Curcuma longa L., collected from Nguter, Sukoharjo, Indonesia. Two-dimensional (2D)-NMR techniques were applied to further identify a number of different types of compounds. Multivariate data analysis such as Principal Component Analysis (PCA) applied to reveal differences among species. A clear difference occurred among 3 Curcuma species. Primary metabolites responsible for the discrimination are alanine (C. xanthorrhiza Roxb. was 3.78 times higher than in $C$. longa $\mathrm{L}$ ), sugars (C. xanthorrhiza Roxb. were 6.03 and 3.81 times higher in $C$. aeruginosa Roxb. and $C$. longa L. respectively). Besides, secondary metabolites which differed among 3 species are curcumin (C. xanthorrhiza Roxb. were 38.25 and 25 times higher than in $C$. aeruginosa Roxb.) and xanthorrhizol (C. longa L. were 62 and 44.4 times higher than in $C$ aeruginosa Roxb.).
\end{abstract}

Keywords: Curcuma aeruginosa; Curcuma xanthorrhiza, Curcuma longa, ${ }^{1} \mathrm{H}-\mathrm{NMR}$, metabolomics, PCA, Secondary metabolites

\section{INTRODUCTION}

The Zingiberaceae contains more less 50 genera and 1000 species. Genus Curcuma, such as turmeric (C. longa L.), temulawak (C. xanthorrhiza Roxb.) and temu ireng $(C$. aeruginosa Roxb.) is one of genus widely used as medicinal herbs in Indonesia. It is 
reported to have numerous uses in health as an antioxidant (Jantan et al., 2012), antimicrobial (Mary et al., 2012), antitumor (Yue et al., 2010 and Choi et al., 2004) and anti-inflammatory (Lantz et al., 2005). The bioactivities of herbal medicine are determined by the chemical compounds, both secondary and primary metabolites.

The major secondary metabolites of genus Curcuma are curcuminoids and terpenoids. The former consists of curcumin, demethoxycurcumin, and bisdemethoxycurcumin (Hadi et al., 2018 and Asghari et al., 2010). The main terpenoids in genus Curcuma are monoterpene and sesquiterpene ( $\mathrm{Li}$ et al., 2011). Those are germacrone, 1,8-cineol, ar-turmerone, $\beta$-sesquiphellandrene (Lee et al., 2014), curcuminol, ar-curcumin (Li et al., 2011) and xanthorrhizol (Jantan et al., 2012). Metabolite profiling of $C$. aromatica and C. longa L. grown in Korea resulted in sugars (glucose, sucrose and fructose) and essential oils (eucalyptol, curdione, and germacrone) as primary and secondary metabolites, respectively were significantly different between two species (Jung et al., 2012). However, limited studies are in metabolites profiling in other species of genus Curcuma. Therefore, knowledge of a simultaneous analysis of both primary and secondary metabolites in other species of genus Curcuma need to be more studied.

Metabolomics is a set of identification and quantification of all metabolites present in biological samples. It applies a technique of chemical analysis which is unbiased, rapid, reproducible and stable during the time. Moreover, it requires simple sample preparation. Nuclear magnetic resonance (NMR) has been widely used to do metabolic profiling with multivariate data analysis such as principal component analysis (PCA). This combined analysis has been reported several studies green tea (Tarachiwin et al., 2007), grapes (Ali et al., 2011b) and Angelica gigas (Kim et al., 2011). A powerful technique for characterization different species (Choi et al., 2005).

In this study, we aimed to investigate a metabolic characterization of three species in genus Curcuma (Zingiberaceae). The species are C. longa L., C. aeruginosa Roxb., and C. xanthorrhiza Roxb. To elaborate the differences, ${ }^{1} \mathrm{H}-\mathrm{NMR}$ coupled with $2 \mathrm{D}$ NMR techniques combined with PCA was applied.

\section{EXPERIMENTAL DETAIL}

Methanol d-4 (CD $\left.{ }_{3} \mathrm{OD}\right)$ 99.95\% (Merck); potassium phosphate $\left(\mathrm{KH}_{2} \mathrm{PO}_{4}\right)($ Merck); $0.01 \%$ TSP (Chem Cruz); buffer $\mathrm{D}_{2} \mathrm{O}, \mathrm{NaOD} 1 \mathrm{M}$ (Santa Cruz Biotechnology). All solvent used are NMR-deurated specification. 
Rhizome from 3 species in genus Curcuma were C. longa L., C. xanthorriza Roxb., and $C$. aeruginosa Roxb. They were collected at Tanggungrejo Village, Nguter District, Sukoharjo Regency at 8 months planting. Each species has three replicates. All samples were cut and ground into fine powder. It kept at $-40{ }^{\circ} \mathrm{C}$ and freeze-dryed.

\section{Extraction and NMR Measurements}

An extraction process referred to the study by Kim et al. (2010). $30 \mathrm{mg}$ of freezedryed plant material was added into $2 \mathrm{~mL}$ eppendorf tube. $630 \mu \mathrm{L}$ of $\mathrm{CD}_{3} \mathrm{OD}$ and $270 \mu \mathrm{L}$ of buffer $\mathrm{KH}_{2} \mathrm{PO}_{4}$ with $0.01 \%$ of TSP diluted in $\mathrm{D}_{2} \mathrm{O}$ were added into the sample. The mixture was vortexed for 1 minute at room temperature then sonicated for 20 minutes. The mixture was centrifuged for 10 minutes at $13,300 \mathrm{rpm}$ at room temperature $\left(28{ }^{\circ} \mathrm{C}\right)$. Supernatant $(600 \mu \mathrm{L})$ from centrifugation process was finally transferred into $5 \mathrm{~mm}$ NMR tube.

${ }^{1} \mathrm{H}-\mathrm{NMR}$ and 2D-NMR were recorded at $25^{\circ} \mathrm{C}$ on a $400 \mathrm{MHz}$ Agilent P. Deurated water were used as the internal lock. Each ${ }^{1} \mathrm{H}$-NMR spectrum scanned 128 times with the following parameters: relaxation delay $=2.0 \mathrm{~s}$ and pulse width $(\mathrm{PW})=90^{\circ}(6.80 \mu \mathrm{s})$. The residual $\mathrm{H}_{2} \mathrm{O}$ signal was suppressed using a pre-saturated sequence with low power selective irradiation at the $\mathrm{H}_{2} \mathrm{O}$ frequency during the recycle delay. Pre-processed steps such as phasing, baseline correction and calibrated to TSP at $0.00 \mathrm{ppm}$ using XWIN NMR. NMR spectra were examined using 2D NMR consist of ${ }^{1} \mathrm{H}-{ }^{1} \mathrm{H}$ J-resolved and ${ }^{1} \mathrm{H}-{ }^{1} \mathrm{H}$ Correlation Spectroscopy (COSY), then compared with literature.

\section{Data analysis and statistical methods}

${ }^{1} \mathrm{H}-\mathrm{NMR}$ spectra were reduced to ASCII files. Spectral intensities were scaled to internal standard and reduce to integrated regions of equal width (0.04) corresponding to the region of $\delta_{\mathrm{H}} 0.0-10.0$. Residual signal of $\mathrm{D}_{2} \mathrm{O}$ and $\mathrm{CD}_{3} \mathrm{OD}$ at the region of 4.85-4.95 and 3.2-3.4 were excluded from the analysis, respectively. Bucketing was performed by AMIX software (Bruker) with scaling on internal standard. Data from ${ }^{1} \mathrm{H}-\mathrm{NMR}$ spectroscopy was analyzed with multivariate statistical analysis using SIMCA-P version 15.0. Multivariate statistical analysis was done using Principal Component Analysis (PCA) method based on species differences.

Data analysis was done using The One-way Analysis of Variance (ANOVA) with significant level 95\%. Post hoc test, LSD, was done to determine which groups differ significantly. 


\section{RESULTS AND DISCUSSION}

${ }^{1} \mathrm{H}-\mathrm{NMR}$ spectra in general divided by three regions, amino acids and organic acids $\left(\delta_{\mathrm{H}} 0.5-2.5\right) \mathrm{ppm}$, sugars $\left(\delta_{\mathrm{H}} 2.5-5.5\right) \mathrm{ppm}$, and aromatic compounds $\left(\delta_{\mathrm{H}} 5.5-8.0\right) \mathrm{ppm}$. To identify metabolite in ${ }^{1} \mathrm{H}-\mathrm{NMR}, 2 \mathrm{D}{ }^{1} \mathrm{H}-{ }^{1} \mathrm{H} J$-resolved and correlation 2D-NMR COSY were used to provide additional information on each signal.

Amino acids identified were alanine, valine and threonine. Alanine proton signal identified at $\delta_{\mathrm{H}} 1.49 \mathrm{ppm}(\mathrm{d}, J=7.13 \mathrm{~Hz}, \mathrm{H}-6)$ and $\delta_{\mathrm{H}} 3.76 \mathrm{ppm}(\mathrm{q}, J=6.36 \mathrm{~Hz}, \mathrm{H}-4)$. Correlation of signals of H-6 and H-4 was observed in the COSY spectrum. Signals at $\delta_{\mathrm{H}}$ $1.02 \mathrm{ppm}(\mathrm{d}, J=7 \mathrm{~Hz}, \mathrm{H}-8), \delta_{\mathrm{H}} 1.07 \mathrm{ppm}(\mathrm{d}, J=7 \mathrm{~Hz}, \mathrm{H}-7)$, and $\delta_{\mathrm{H}} 3.79 \mathrm{ppm}(\mathrm{m}, \mathrm{H}-6)$ were identified as valine. Signals at $\delta_{\mathrm{H}} 1.33 \mathrm{ppm}(\mathrm{d}, J=6.82 \mathrm{~Hz}, \mathrm{H}-8), \delta_{\mathrm{H}} 3.53 \mathrm{ppm}(\mathrm{d}, J=$ $4.72 \mathrm{~Hz}, \mathrm{H}-4)$, and $\delta_{\mathrm{H}} 4.04 \mathrm{ppm}(\mathrm{m}, \mathrm{H}-6)$ were associated to threonine. Correlation between signals at $\delta_{\mathrm{H}} 1.33 \mathrm{ppm}(\mathrm{H}-8)$ and $\delta_{\mathrm{H}} 3.53 \mathrm{ppm}(\mathrm{H}-4)$ with $\delta_{\mathrm{H}} 4.04 \mathrm{ppm}(\mathrm{H}-6)$ was observed in the COSY spectrum.

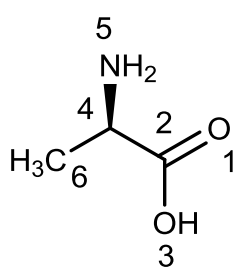

Alanine

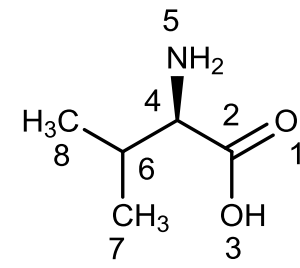

Valine

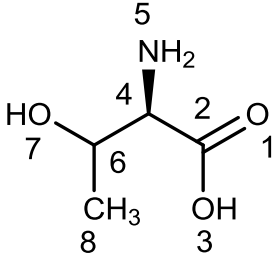

Threonine

Sugars regions were identified as $\alpha$-glucose, $\beta$-glucose, fructose and sucrose. Signal of $\delta_{\mathrm{H}} 5.17 \mathrm{ppm}(\mathrm{d}, J=3,94 \mathrm{~Hz}), \delta_{\mathrm{H}} 4.56 \mathrm{ppm}(\mathrm{d}, J=8.24 \mathrm{~Hz})$, and $\delta_{\mathrm{H}} 5.41 \mathrm{ppm}(\mathrm{d}, J=3,96$ $\mathrm{Hz}$ ) were identified as $\alpha$-Glucose, $\beta$-glucose and sucrose, respectively. Formic acid was identified by proton signal at $\delta_{\mathrm{H}} 8.49 \mathrm{ppm}$ singlet.<smiles>COc1cc(/C=C/C(=O)CC(=O)/C=C/c2ccc(O)c(OC)c2)ccc1O</smiles>

Curcumin

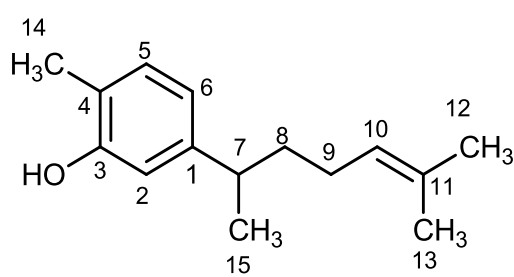

Xanthorrhizol

Figure 1. Secondary metabolite structures

Phenolic and terpenoid as major compounds were curcumin and xanthorrhizol identified in genus Curcuma, respectively (Figure 1). Signals at $\delta_{\mathrm{H}}(\mathrm{ppm}): 3.92$ (s, H-7/7'), 6.64 (d, $\left.J=15.68 \mathrm{~Hz}, \mathrm{H}-3 / 3^{\prime}\right), 7.57$ (d, $\left.J=15.68 \mathrm{~Hz}, \mathrm{H}-4 / 4^{\prime}\right), 6.89$ (d, $J=8.59 \mathrm{~Hz}, \mathrm{H}-$ 
9/9'), and 7.15 (dd, $J=8.21 ; 3.16 \mathrm{~Hz}, \mathrm{H}-10 / 10^{\prime}$ ) were identified as curcumin. ${ }^{1} \mathrm{H}-{ }^{1} \mathrm{H}$ COSY spectra showed a signal correlation between $\mathrm{H}-3 / 3^{\prime}$ and $\mathrm{H}-4 / 4^{\prime}$. Besides signal $\mathrm{H}-$ 9/9' and H-10/10' were correlated in ${ }^{1} \mathrm{H}^{1}{ }^{1} \mathrm{H}$ COSY spectra. Signals at $\delta_{\mathrm{H}}(\mathrm{ppm}): 1.87$ (s, H12), 1.93 (s, H-13), 2.00 (s, H-14), 1.22 (d, $J=7.06 \mathrm{~Hz}, \mathrm{H}-15), 2.69$ (q, $J=7.35 \mathrm{~Hz}, \mathrm{H}-7$ ), 7.23 (d, $J=3.05 \mathrm{~Hz}, \mathrm{H}-2), 7.57$ (dd, $J=8.21 ; 3.16 \mathrm{~Hz}, \mathrm{H}-6)$, and 6.89 (d, $J=8.59 \mathrm{~Hz}, \mathrm{H}-$ 5) were assigned as xanthorrhizol. Correlation between $\mathrm{H}-15$ and $\mathrm{H}-7$ were shown in ${ }^{1} \mathrm{H}-$

${ }^{1} \mathrm{H}$ COSY spectra. Besides, both signals at $\mathrm{H}-5 / \mathrm{H}-2$ and $\mathrm{H}-6$ were correlated in ${ }^{1} \mathrm{H}-{ }^{1} \mathrm{H}$ COSY spectra.

Table 1. ${ }^{1} \mathrm{H}-\mathrm{NMR}$ chemical shifts $(\delta)$ and coupling constants $(\mathrm{Hz})$ of compounds identified in genus Curcuma ( $C$. aeruginosa, $C$. xanthorrhiza, and $C$. longa) using $1 \mathrm{D}$ and 2D NMR spectra. It dissolved in $\mathrm{CD}_{3} \mathrm{OD}-\mathrm{KH}_{2} \mathrm{PO}_{4}$ in $\mathrm{D}_{2} \mathrm{O}$, pH 6.0

\begin{tabular}{|c|c|}
\hline Metabolites & Chemical shift $(\delta)$ and copling constants $(\mathrm{Hz})$ \\
\hline Alanine & $1.49(\mathrm{~d}, J=7.13 \mathrm{~Hz}, \mathrm{H}-6), 3.76(\mathrm{q}, J=6.36 \mathrm{~Hz}, \mathrm{H}-4)$ \\
\hline Threonine & $1.33(\mathrm{~d}, J=6.82 \mathrm{~Hz}, \mathrm{H}-8), 3.53(\mathrm{~d}, J=4.72 \mathrm{~Hz}, \mathrm{H}-4)$ \\
\hline Valine & $1.02(\mathrm{~d}, J=7.00 \mathrm{~Hz}, \mathrm{H}-8), 1.07(\mathrm{~d}, J=7.00 \mathrm{~Hz}, \mathrm{H}-7)$ \\
\hline$\alpha$-Glucose & $\begin{array}{l}5.17(\mathrm{~d}, J=3.94 \mathrm{~Hz}, \mathrm{H}-1), 3.49(\mathrm{dd}, J=9.72 ; 3.7 \mathrm{~Hz}, \mathrm{H}-2), 3.74(\mathrm{t}, \\
J=9.72 \mathrm{~Hz}, \mathrm{H}-3), 3.42(\mathrm{t}, J=9.62 \mathrm{~Hz}, \mathrm{H}-4)\end{array}$ \\
\hline$\beta$-Glucose & $4,56(\mathrm{~d}, J=8.24 \mathrm{~Hz}, \mathrm{H}-1), 3.19(\mathrm{t}, \mathrm{J}=8.55 \mathrm{~Hz}, \mathrm{H}-2)$ \\
\hline Fructose & $3.99(\mathrm{dd}, J=12.27 ; 3.11 \mathrm{~Hz}, \mathrm{H}-4), 4.16(\mathrm{~d}, J=8.43 \mathrm{~Hz}, \mathrm{H}-3)$ \\
\hline Sucrose & $\begin{array}{l}3.42(\mathrm{t}, J=9.22 \mathrm{~Hz}, \mathrm{H}-10), 3.74(\mathrm{t}, J=9.30 \mathrm{~Hz}, \mathrm{H}-11), 3.49(\mathrm{dd}, J \\
=9.62 ; 4.33 \mathrm{~Hz}, \mathrm{H}-12), 5,41(\mathrm{~d}, J=3.96 \mathrm{~Hz}, \mathrm{H}-7), 3.65(\mathrm{~s}, \mathrm{H}-13)\end{array}$ \\
\hline Cholin & $3.32(\mathrm{~s}), 3.49(\mathrm{dd}, J=9.62 ; 4.33 \mathrm{~Hz})$ \\
\hline Formic Acid & $8.49(\mathrm{~s}, \mathrm{H}-2)$ \\
\hline Curcumin & $\begin{array}{l}3.92\left(\mathrm{~s}, \mathrm{H}-7 / 7^{\prime}\right), 6.64\left(\mathrm{~d}, J=15,68 \mathrm{~Hz}, \mathrm{H}-3 / 3^{\prime}\right), 7.57(\mathrm{~d}, J=15,68 \\
\left.\mathrm{Hz}, \mathrm{H}-4 / 4^{\prime}\right), 6.89\left(\mathrm{~d}, J=8.59, \mathrm{H}-9 / 9^{\prime}\right), 7.15(\mathrm{dd}, J=8.21 ; 3.16 \mathrm{~Hz}, \\
\left.\mathrm{H}-10 / 10^{\prime}\right)\end{array}$ \\
\hline Xanthorrhizol & $\begin{array}{l}1,87(\mathrm{~s}, \mathrm{H}-12), 1.93(\mathrm{~s}, \mathrm{H}-13), 2.00(\mathrm{~s}, \mathrm{H}-14), 1.22(\mathrm{~d}, J=7.06 \mathrm{~Hz} \\
\mathrm{H}-15), 2.69(\mathrm{q}, J=7,35 \mathrm{~Hz}, \mathrm{H}-7), 7.23(\mathrm{~d}, J=3.05 \mathrm{~Hz}, \mathrm{H}-2), 7.57 \\
(\mathrm{dd}, J=8.21 ; 3.16 \mathrm{~Hz}, \mathrm{H}-6), 6.89(\mathrm{~d}, J=8.59 \mathrm{~Hz}, \mathrm{H}-5)\end{array}$ \\
\hline
\end{tabular}

Multivariate data analysis particularly PCA was used to identify differences in data (Jung et al., 2012). PCA is an unsupervised and clustering method to reduce the dimensionality of multivariate data. The principal components (PCs) are shown in a graphical form as a score plot. It is useful to identify any groupings in the data set. Loading plots are shown from coefficients by which the original variables must be multiplied to obtain the PCs (Kim et al., 2010). Loading plots are useful to detect the spectral areas responsible for the separation of the data.

Scoring plot of PCA showed $63.1 \%$ separation in PC1; C. xanthorrhiza Roxb. and C. longa L. extracts were grouped in positive quadrant while $C$. aeruginosa Roxb. extract was grouped in negative quadrant (Figure 2A). PCA loading plot resulted in signals 
responsible for the separation (Figure 2B). Amino acids such as alanine, valine, and threonine showed to have higher signals at $C$. aeruginosa Roxb.. On the other hands, sugars ( $\alpha$-glucose, $\beta$-glucose, fructose and sucrose), phenolic (curcumin), and terpenoid (xanthorrhizol) compounds found to be discriminating for $C$. xanthorrhiza Roxb. and $C$. longa $\mathrm{L}$.
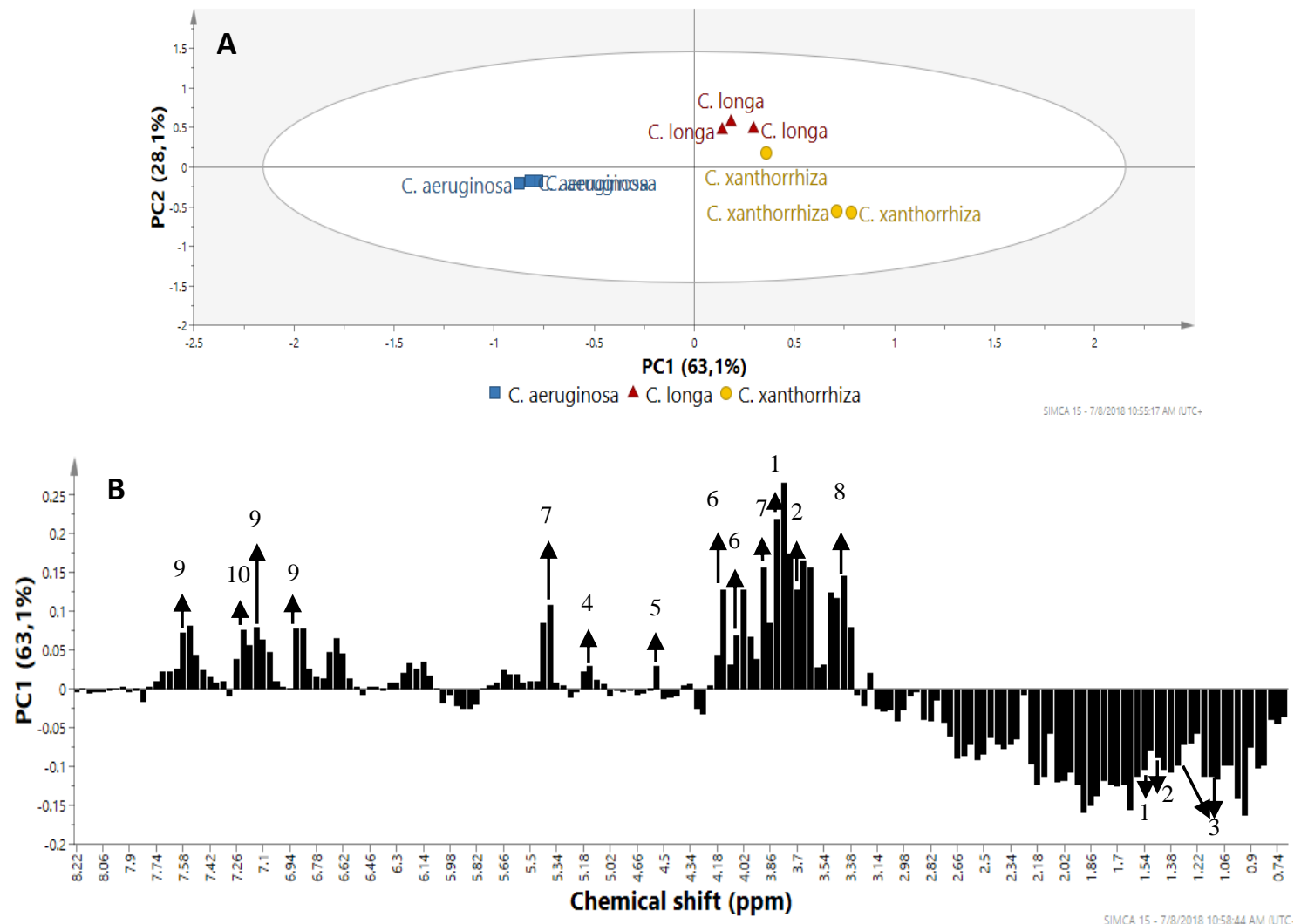

Figure 2. Scoring plot (A) and loading plot (B) of PCA in genus Curcuma. Metabolites identified are (1) alanine, (2) threonine, (3) valine, (4) $\alpha$-glucose, (5) $\beta$-glucose, (6) fructose, (7) sucrose, (8) choline, (9) curcumin, (10) xanthorrhizol.

Relative concentration of alanine, $\alpha$-glucose, sucrose, fructose dan choline showed significant differences among species $(\mathrm{F}=5,8 ; \mathrm{df}=2 ; p=0,040 ; \mathrm{F}=8,953 ; \mathrm{df}=2 ; p=$ 0,$016 ; \mathrm{F}=14,496 ; \mathrm{df}=2 ; p=0,002 ; \mathrm{F}=17,863 ; \mathrm{df}=2 ; p=0,003 ; \mathrm{F}=27,636 ; \mathrm{df}=2 ; p=$ 0,001, respectively). Alanine relative concentration in C. xanthorrhiza Roxb. were 3.78 times and 1.3 times higher than in $C$. longa L. and in $C$. aeruginosa Roxb. Relative concentration of $\alpha$-glucose in $C$. xanthorrhiza Roxb. was 6.2 times higher than in $C$. aeruginosa Roxb., while relative concentration in C. xanthorrhiza Roxb. was 3.9 times higher than in C. longa L. Sucrose relative concentration in C. xanthorrhiza Roxb. was 6.08 times higher than in $C$. aeruginosa Roxb., whilst relative concentration in $\mathrm{C}$. xanthorrhiza Roxb. was 3.6 times higher than in C. longa L. Fructose relative concentration in $C$. xanthorrhiza Roxb. were 5.8 times and 3.93 times higher than in $C$. 
aeruginosa Roxb. and $C$. longa $\mathrm{L}$ respectively. Relative concentrations of choline in $C$. xanthorrhiza Roxb. were 4.09 and 3.03 times higher than in $C$. aeruginosa Roxb. and $C$. longa L., respectively. Primary metabolites such as alanine, $\alpha$-glucose, sucrose, fructose (Figure 3) differed significantly between C. aromatica and C. longa grown in Korea (Jung et al., 2012).

Secondary metabolite concentrations of curcumin and xanthorrhizol also showed significant differences among species $(\mathrm{F}=13,735 ; \mathrm{df}=2 ; p=0,006$ and $\mathrm{F}=15,297 ; \mathrm{df}=2$; $p=0,004$, respectively). Those compounds (Figure 3) were not present in $C$. aeruginosa Roxb.. Curcumin relative concentration in C. xanthorrhiza Roxb. was 38.25 times higher than in $C$. aeruginosa Roxb., while curcumin relative concentrations in $C$. longa L. were 62 times and 1.62 times higher than in $C$. aeruginosa Roxb. and $C$. xanthorrhiza Roxb. respectively. Xanthorrhizol relative concentration in C. xanthorrhiza Roxb. was 25 times higher than in $C$. aeruginosa Roxb., whereas xanthorrhizol relative concentration in $C$. longa $\mathrm{L}$. was 44.4 times and 1.78 times higher than in $C$. aeruginosa Roxb. and in $C$. xanthorrhiza Roxb. respectively. Curcumin and xanthorrhizol in C. xanthorrhiza Roxb. and C. longa. reported present in C. xanthorrhiza Roxb. (Rafi et al., 2015; Lechtenberg et al., 2004). Xanthorrhizol was the major compound in C. xanthorrhiza Roxb. (Ab Halim et al., 2012). However, Jarikasem et al. (2003) reported that xanthorrhizol was not identified in $C$. xanthorrhiza. This difference might be due to the rhizome age which has the optimum abundance at 12 months planting (Endrasari and Mas'adi, 2011). Curcumin in $C$. longa was two times higher than in $C$. xanthorrhiza Roxb.. Curcumin has been reported to have the highest abundance $3.6 \%$ in $C$. longa L. than in C. xanthorrhiza Roxb. (2.3\%) (Jantan et al., 2012). 

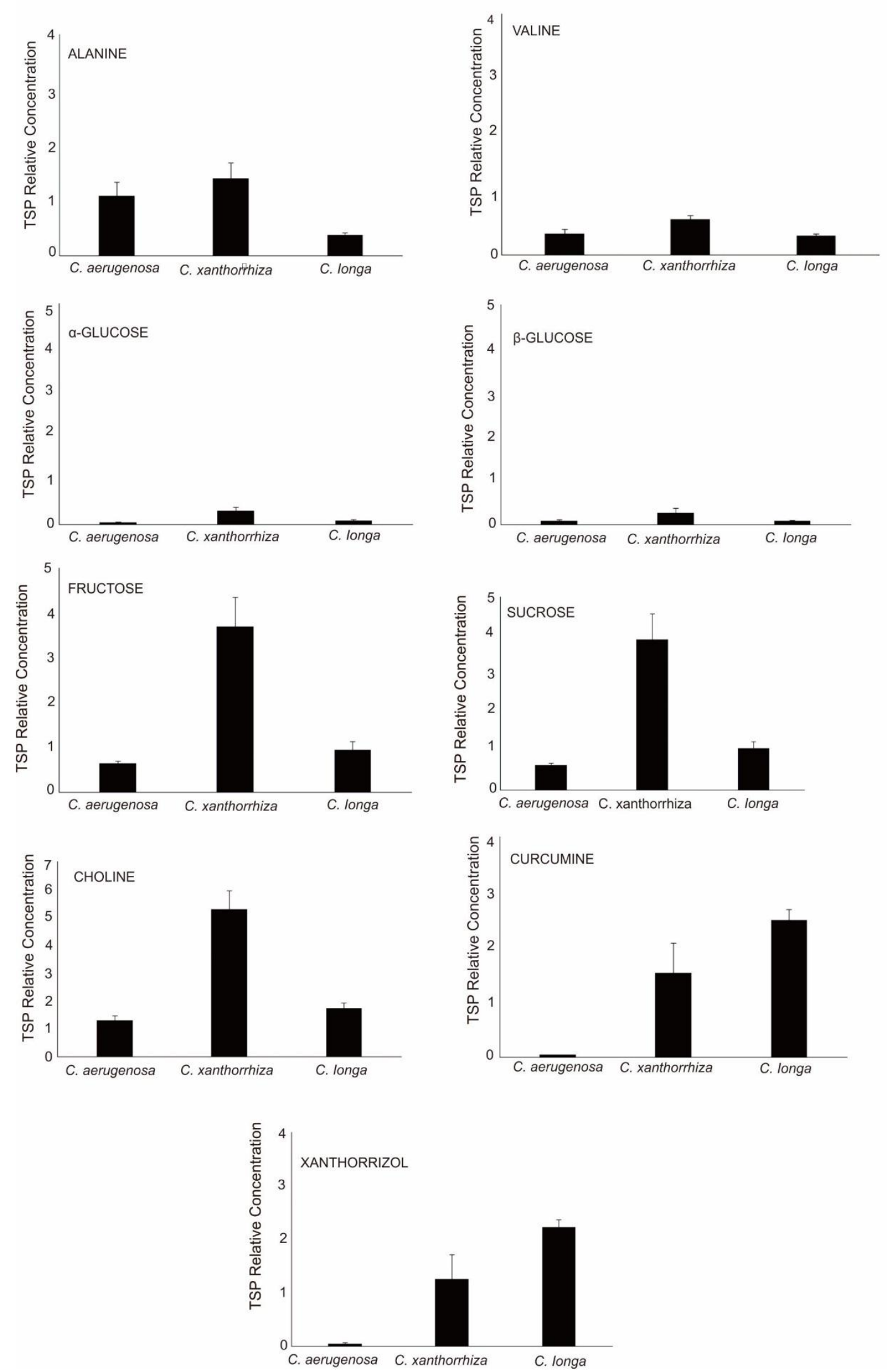

Figure 3. ANOVA metabolite quantification $(p<0.05)$ of Curcuma extracts that were analyzed using ${ }^{1} \mathrm{H}-\mathrm{NMR}$. Different letter indicated significant values at $95 \%$ confidence level. 


\section{CONCLUSION}

Profiling metabolites in three species of Curcuma (C. aeruginosa Roxb., C. longa L., and C. xanthorrhiza Roxb.) can be done using metabolomic study based on ${ }^{1} \mathrm{H}-\mathrm{NMR}$. It could differ three Curcuma species significantly by either primary and secondary metabolites. The former were alanine, $\alpha$-glucose, sucrose, fructose and choline, and the latter were curcumin and xanthorrhizol. Those metabolites showed a particular profile which was potentially useful as a marker of species. The study of other Curcuma species needs to be done to enlarge the knowledge of Curcuma genera metabolite profiling.

\section{ACKNOWLEDGEMENT}

The first author thanks to the Natural Medicine research study. This work was supported by PNBP Universitas Sebelas Maret, 2018. The authors declared no potential conflict of interest in this study.

\section{REFERENCES}

Ab Halim, M.R., Tan, M.S.M.Z., Ismail, S., and Mahmud, R., 2012. Standardization and Phytochemical Studies of Curcuma Xanthorrhiza Roxb. International Journal of Pharmacy and Pharmaceutical Sciences 4(3), 606-610.

Asghari, G., Mostajeran, A. and Shebli, M., 2010. Curcuminoid and Essential Oil Components of Turmeric at Different Stages of Growth Cultivated in Iran', Research in Pharmaceutical Sciences 4(1), 55-61.

Choi, M.A., Kim, S.H., Chung, W.Y., Hwang, J.K., and Park, K.K., 2004. Xanthorrhizol, a Natural Sesquiterpenoid from Curcuma Xanthorrhiza, Has an Anti-Metastatic Potential in Experimental Mouse Lung Metastasis Model. Biochemical and Biophysical Research Communications 326(1), 210-217.

Choi, Y.H., Sertic, S., Kim, H.K., Wilson, E.G., Michopoulos, F., Lefeber, A.W., and Verpoorte, R., 2005. Classification of Ilex Species Based on Metabolomic Fingerprinting Using Nuclear Magnetic Resonance and Multivariate Data Analysis. Journal of Agricultural and Food Chemistry 53(4), 1237-1245.

Endrasari, R. and Mas'adi, T., 2011. Innovation of Postharvest Technology To Improve The Quality of Simplicia Temulawak (Curcuma Xanthorrhiza Roxb.). Biopharmaca Research Center.

Hadi, S., Artanti, A.N., Rinanto, Y., and Wahyuni, D.S.C., 2018. Curcuminoid Content of Curcuma Longa L. and Curcuma Xanthorrhiza Rhizome Based on Drying Method with NMR and HPLC-UVD. In IOP Conference Series: Materials Science and Engineering (Vol. 349, No. 1, p. 012058). IOP Publishing.

Jantan, I., Saputri, F.C., Qaisar, M.N., and Buang, F., 2012. Correlation Between Chemical Composition of Curcuma Domestica and Curcuma Xanthorrhiza and Their Antioxidant Effect on Human Low-Density Lipoprotein Oxidation. Evidence-Based Complementary and Alternative Medicine. 
Jarikasem, S., Thubthimthed, S., Chawananoraseth, K., and Suntorntanasat, T., 2003. Essential Oils from Three Curcuma Species Collected in Thailand. In III WOCMAP Congress on Medicinal and Aromatic Plants-Volume 3: Perspectives in Natural Product Chemistry 677, 37-41).

Jung, Y., Lee, J., Kim, H.K., Moon, B.C., Ji, Y., and Hwang, G.S., 2012. Metabolite Profiling of Curcuma Species Grown in Different Regions Using ${ }^{1} \mathrm{H}$ NMR Spectroscopy and Multivariate Analysis. Analyst 137(23), 5597-5606.

Kim, E.J., Kwon, J., Park, S.H., Park, C., Seo, Y.B., Shin, H.K. and Hwang, G.S., 2011. Metabolite Profiling of Angelica Gigas from Different Geographical Origins Using $1 \mathrm{H}$ NMR and UPLC-MS Analyses. Journal of Agricultural and Food Chemistry 59(16), 8806-8815.

Kim, H.K., Choi, Y.H. and Verpoorte, R., 2010. NMR-Based Metabolomic Analysis of Plants. Nature protocols 5(3), 536-549.

Lantz, R.C., Chen, G.J., Solyom, A.M., Jolad, S.D., and Timmermann, B.N., 2005. The Effect of Turmeric Extracts on Inflammatory Mediator Production. Phytomedicine 12(6-7), 445-452.

Lechtenberg, M., Quandt, B., and Nahrstedt, A., 2004. Quantitative Determination of Curcuminoids in Curcuma Rhizomes and Rapid Differentiation of Curcuma Domestica Val. and Curcuma Xanthorrhiza Roxb. by Capillary Electrophoresis. Phytochemical Analysis: An International Journal of Plant Chemical and Biochemical Techniques, 15(3), 152-158.

Lee, J., Jung, Y., Shin, J.H., Kim, H.K., Moon, B.C., Ryu, D.H., and Hwang, G.S., 2014. Secondary Metabolite Profiling of Curcuma Species Grown at Different Locations Using GC/TOF and UPLC/Q-TOF MS. Molecules 19(7), 9535-9551.

Li, S., Yuan, W., Deng, G., Wang, P., Yang, P., and Aggarwal, B., 2011. Chemical Composition and Product Quality Control of Turmeric (Curcuma Longa L.). Pharmaceutical Crops 2(1).

Mary, H.P., Susheela, G.K., Jayasree, S., Nizzy, A.M., Rajagopal, B., and Jeeva, S., 2012. Phytochemical Characterization and Antimicrobial Activity of Curcuma Xanthorrhiza Roxb. Asian Pacific Journal of Tropical Biomedicine 2(2), S637S640.

Rafi, M., Wulansari, L., Heryanto, R., Darusman, L.K., Lim, L.W., and Takeuchi, T., 2015. Curcuminoid's Content and Fingerprint Analysis for Authentication and Discrimination of Curcuma Xanthorrhiza from Curcuma Longa by HighPerformance Liquid Chromatography-diode Array Detector. Food analytical methods 8(9), 2185-2193.

Tarachiwin, L., Ute, K., Kobayashi, A., and Fukusaki, E., 2007. 1H NMR Based Metabolic Profiling in The Evaluation of Japanese Green Tea Quality. Journal of Agricultural and Food Chemistry 55(23), 9330-9336.

Yue, G.G., Chan, B.C., Hon, P.M., Lee, M.Y., Fung, K.P., Leung, P.C., and Lau, C.B., 2010. Evaluation of In Vitro Anti-Proliferative and Immunomodulatory Activities of Compounds Isolated from Curcuma Longa. Food and Chemical Toxicology 48(8-9), 2011-2020. 